\title{
Obwieszczenie Prezydenta RP o wolnych stanowiskach sędziowskich w Sądzie Najwyższym - akt urzędowy czy czynność urzędowa?
}

\author{
A notice of the President of the Republic of Poland on vacant judgeships \\ in the Supreme Court - an official document or action? \\ Объявление Президента Республики Польша о судебных вакансиях \\ в Верховном суде - официальный акт или официальное действие?
}

\author{
JACEK WIDŁO \\ Dr hab., prof. Katolickiego Uniwersytetu Lubelskiego Jana Pawła II \\ e-mail: j.widlo@kul.pl, https://orcid.org/0000-0003-2685-8155
}

\begin{abstract}
Streszczenie: W artykule przeanalizowano charakter prawny czynności urzędowej Prezydenta RP - obwieszczenia o wolnych stanowiskach (art. $31 \S 1$ ustawy o Sądzie Najwyższym). Spróbowano rozstrzygnąć problem wymogu uzyskania przez Prezydenta RP kontrasygnaty Prezesa Rady Ministrów dla tego obwieszczenia. Sformowano wnioski, iż: obwieszczenie Prezydenta RP wydane w trybie art. 31 § 1 ustawy o Sądzie Najwyższym jest czynnością urzędową Prezydenta RP, która w przeciwieństwie do aktów urzędowych Prezydenta RP nie wymaga kontrasygnaty. W przypadku przyjęcia odmiennego poglądu i zakwalifikowania obwieszczenia Prezydenta RP wydanego w trybie art. 31 § 1 ustawy o Sądzie Najwyższym, jako aktu urzędowego Prezydenta RP, nie wymaga on kontrasygnaty, gdyż: mieści się to w koncepcji kompetencji pochodnej wynikającej z prerogatywy Prezydenta RP - art. 144 ust. 3 pkt 17 Konstytucji RP; wymaganie kontrasygnaty byłoby sprzeczne z Konstytucją - sprzeczna z art. 10 i art. 179 Konstytucji RP czynność obwieszczenia o wolnych stanowiskach sędziowskich stanowi obowiązek, a nie uprawnienie Prezydenta RP.
\end{abstract}

Słowa kluczowe: obwieszczenie o wolnych stanowiskach sędziowskich, obowiązek uzyskania kontrasygnaty, prerogatywa prezydencka

Summary: The article analyses the legal nature of an official action taken by the President of the Republic of Poland - a notice on free judgeships (Article $31 \S 1$ of the Law on the Supreme Court). It attempts to determine whether the President of the Republic of Poland is required to obtain a countersignature, for such a notice, from the Prime Minister. The following conclusions have been formulated: a notice of the President of the Republic of Poland issued under Article $31 \S 1$ of the Law on the Supreme Court is an official action of the President of the Republic of Poland which, contrary to official acts of the President of Poland, does not require a countersignature. Should a different view be adopted according to which a notice of the President of Poland issued under Article $31 \S 1$ of the Law on the Supreme Court is qualified as an act of the President of the Republic of Poland, it does not require a countersignature because it is included in the concept of a derivative competence following from the prerogative of the President of the Republic of Poland pursuant to Article 144, Clause 3, Sub-clause 17 of the Constitution of the Republic of Poland. The requirement of a countersignature would be contrary to Article 10 and Article 179 of the Constitution of the Republic of Poland. The action of publishing a notice on vacant judgeships is an obligation, not a right of the President of the Republic of Poland.

Key words: notice on vacant judgeships, obligation to obtain a countersignature, prerogative of the President

Резюме: В статье анализируется правовая природа официального действия Президента Республики Польша - объявления о вакансиях (ст. 31 § 1 пВС). Предпринята попытка решить проблему, связанную с требованием к Президенту Республики Польша получить контрасигнатуру Премьер-министра для 
этого объявления. В статье сформулирован вывод, что: объявление Президента Республики, изданное в соответствии со статьей 31 § 1 пВС, является официальным действием Президента РП, которое, в отличие от официальных актов Президента РП, не требует контрасигнатуры. Если придерживаться противоположной точки зрения и квалифицировать объявление Президента РП, в соответствии со ст. 31 $\S 1$ пВС, как официальный акт Президента РП, то оно не требует контрасигнатуры, поскольку подпадает под понятие производной компетенции, вытекающей из прерогативы Президента РП (ст. 144 ч. 3 п. 17 Конституции Республики Польша); требование контрасигнатуры противоречило бы Конституции - противоречивое ст. 10 и ст. 179 Конституции Республики Польша действие по объявлению вакантных должностей судей является обязанностью, а не полномочием Президента Республики Польша.

Ключевые слова: объявление о вакансиях судей, требование получения контрасигнатуры, прерогатива президента

\section{Wstęp}

Przy rozważaniu problematyki obwieszczenia Prezydenta RP o wolnych stanowiskach sędziowskich w Sądzie Najwyższym pojawia się zagadnienie wymogu uzyskania przez Prezydenta RP kontrasygnaty Prezesa Rady Ministrów dla tej czynności. Problem dotyczy konieczności rozstrzygnięcia:

1) czy obwieszczenie, o którym mowa w art. $31 \S 1$ ustawy o Sądzie Najwyższym ${ }^{1}$, ma charakter aktu urzędowego, a następnie - w wypadku pozytywnej odpowiedzi,

2) czy mieści się ono w zakresie prerogatywy Prezydenta RP z art. 144 ust. 3 pkt 17 Konstytucji RP albo czy wymaga kontrasygnaty Prezesa Rady Ministrów.

\section{Funkcje obwieszczenia o wolnych stanowiskach sędziowskich}

Zgodnie $z$ art. $31 \S 1$ ustawy o Sądzie Najwyższym Prezydent Rzeczypospolitej Polskiej, po zasięgnięciu opinii Pierwszego Prezesa Sądu Najwyższego, obwieszcza w Dzienniku Urzędowym Rzeczypospolitej Polskiej „Monitor Polski” liczbę wolnych stanowisk sędziego przewidzianych do objęcia w poszczególnych izbach Sądu Najwyższego.

W tym zakresie pojęcie „obwieszcza” oznacza: „informuje, podaje do publicznej wiadomości”, tzn. w sposób formalny informację o wolnych stanowiskach sędziowskich. Ogłoszenie to jest warunkiem koniecznym procedury inicjującej wykonanie

1 Ustawa z dnia 8 grudnia 2017 r. o Sądzie Najwyższym, tekst jednolity: Dz. U. z 2019 r. poz. 825; z 2020 r. poz. 190. 
prerogatywy Prezydenta RP wynikającej z art. 144 ust. 3 pkt 17 Konstytucji RP ${ }^{2}$ dotyczącej powoływania sędziów.

\subsection{Obwieszczenie o wolnych stanowiskach w sądach powszechnych}

W przypadku sądów powszechnych procedurę konkursową na stanowisko sędziego sądu powszechnego uruchamia obwieszczenie Ministra Sprawiedliwości. Zgodnie z art. 20a $\$ 4$ ustawy z dnia z dnia 27 lipca 2001 r. - Prawo o ustroju sądów powszechnych ${ }^{3}$ „o wolnych stanowiskach sędziowskich Minister Sprawiedliwości obwieszcza w Dzienniku Urzędowym Rzeczypospolitej Polskiej «Monitor Polski»”. Czynność ta nie ma charakteru władczego, ale pełni funkcję informacyjną i formalnie rozpoczyna procedurę konkursową na wolne stanowisko sędziowskie, co wymaga publikacji obwieszczenia w dzienniku urzędowym „Monitor Polski”. Reguła ta podkreśla transparentny charakter procedury, równość szans, jednolite reguły postępowania ${ }^{4}$. Jednocześnie ten sam przepis w art. 20a $\$ 1$ u.s.p. przewiduje upoważnienie ustawowe dla Ministra Sprawiedliwości do przydzielania nowych stanowisk sędziowskich oraz asesorskich poszczególnym sądom. Kompetencja ta ma niewątpliwie charakter władczy i poprzedza ogłoszenie o wolnych stanowiskach sędziowskich. Minister wykonując ją, przydziela wolne stanowiska, „mając na względzie racjonalne wykorzystanie kadr sądownictwa powszechnego, potrzeby wynikające z obciążenia zadaniami poszczególnych sądów”, jak to wynika z upoważnienia ustawowego. Materia tego przepisu była poprzednio regulowana przez uchylony art. 56 u.s.p.

Jak wskazywano, pierwotną wersją art. 56 u.s.p. minister sprawiedliwości ustalał corocznie liczbę wolnych stanowisk dla poszczególnych sądów i następnie obwieszczał o tym w Dzienniku Urzędowym Rzeczypospolitej Polskiej „Monitor Polski” najpóźniej do 1 czerwca każdego roku . Rozdzielenie fazy władczej i informacyjnej utrzymano w obecnie obowiązującym prawie o ustroju sądów powszechnych.

2 Konstytucja Rzeczpospolitej Polskiej z dnia 2 kwietnia 1997, Dz. U. z 1997 r. Nr 78, poz. 483 z późn. zm.

3 Ustawa z dnia 27 lipca 2001 r. - Prawo o ustroju sądów powszechnych, tekst jednolity: Dz. U. z 2020 r. poz. 365 z późn. zm. (dalej: u.s.p).

4 Ma także służyć zwiększeniu konkurencyjności w obsadzie wolnych stanowisk sędziowskich. Na zwolnione stanowiska sędziowskie mogą zgłosić się wszyscy zainteresowani kandydaci, którzy spełniają ustawowe kryteria, tak. S. Dąbrowski, A. Łazarska, Komentarz do art. 56, w: Prawo o ustroju sądów powszechnych. Komentarz, red. A. Górski, 2013 [baza danych LEX].

5 J. Gudowski, T. Ereciński, J. Iwulski, Komentarz do art. 56, Komentarz do Ustawy o Krajowej Radzie Sądownictwa, w: Prawo o ustroju sądów powszechnych. Ustawa o Krajowej Radzie Sądownictwa. Komentarz, red. J. Gudowski, 2009 [baza danych LEX]. 
Dopiero po dokonaniu czynności przydzielenia wolnych stanowisk sędziowskich i ostatecznym ustaleniu przynależności stanowiska do konkretnego sądu, minister sprawiedliwości obwieszcza o wolnym stanowisku sędziowskim w Dzienniku Urzędowym, realizując obowiązek informacyjny.

Przyjmuje się, że to Minister Sprawiedliwości jest dysponentem wolnych stanowisk sędziowskich i odpowiada za ich racjonalne wykorzystanie. Ma on kompetencję nie tylko do przydzielania nowych stanowisk, ale i rozdziału stanowisk zwolnionych ${ }^{6}$. Mieści się to $\mathrm{w}$ ramach nadzoru administracyjnego nad sądami. Przydzielanie wolnych stanowisk sędziowskich ma niewątpliwie charakter władczy, a samo obwieszczenie jest czynnością następczą wobec przydzielenia stanowisk sędziowskich.

Jak zauważono wcześniej, kwestię tę normatywnie rozbito na dwie odrębne jednostki redakcyjne (art. 20a $\$ 1$ i $\$ 4$ u.s.p.). W świetle art. $57 \$ 1$ u.s.p. obwieszczenie o wolnym stanowisku sędziowskim jest równoznaczne z rozpoczęciem procedury jego obsady. Natomiast dopiero zgłoszenie kandydatury przez uczestnika konkursu (kandydata na sędziego) inicjuje już sam konkurs. Brak zgłoszeń powoduje, że konkurs nie zostaje uruchomiony. W założeniu należy analogicznie ujmować funkcje i znaczenie obwieszczenia o wolnych stanowiskach sędziowskich w Sądzie Najwyższym.

\subsection{Obwieszczenie o wolnych stanowiskach sędziowskich w Sądzie Najwyższym}

W przypadku Sądu Najwyższego ustawodawca w obecnie obowiązującej ustawie o SN przyznał Prezydentowi RP uprawnienie do obwieszczania o wolnych stanowiskach sędziego przewidzianych do objęcia w poszczególnych izbach Sądu Najwyższego, w miejsce wcześniejszej czynności obwieszczenia dokonywanej przez Pierwszego Prezesa SN. Należy zastanowić się, czy takie obwieszczenie ma charakter władczy, rozstrzyga o prawach i obowiązkach, czy tylko informacyjny jak w przypadku procedur w sądach powszechnych, wszczynając procedurę naboru na wolne stanowiska w Sądzie Najwyższym, o czym w dalszej części opracowania.

Należy także rozważyć, czy obwieszczenie o wolnych stanowiskach sędziowskich w Sądzie Najwyższym należy kwalifikować jako akt urzędowy Prezydenta RP w rozumieniu art. 144 ust. 1 i 3 Konstytucji RP, czy też jest to czynność Prezydenta RP o charakterze technicznym niewymagająca kontrasygnaty. Należy prześledzić poglądy na temat pojęcia aktu urzędowego Prezydenta RP, a także rozumienia i zakresu kontrasygnaty.

S. Dąbrowski, A. Łazarska, Komentarz do art. 56... 


\section{Pojęcie aktu urzędowego Prezydenta RP}

Po pierwsze, prezentowany jest tradycyjny pogląd rozumienia aktów urzędowych Prezydenta RP, którymi są akty prawne: 1) wydawane w formie pisemnej, 2) dokonywane przez Prezydenta RP w wykonywaniu przyznanych mu konstytucyjnych i ustawowych kompetencji, 3) wywołujące skutki prawne. Przy czym odmiennie rozumie się to, co jest aktem prawnym, w szczególności, czy to taki akt, który ma charakter normatywny i kreuje normę prawną, czy też akt indywidualny kreujący skutki prawne $e^{7}$ Przy tym tradycyjnym poglądzie wskazuje się jednak i wymienia czynności, niebędące aktami urzędowymi Prezydenta RP, które nie spełniając powyżej określonych kryteriów, nie wymagają kontrasygnaty, a jej brak nie wpływa na ważność i skuteczność czynności podjętych przez Prezydenta $\mathrm{RP}^{8}$. Innymi słowy, nie każda czynność Prezydenta RP jest jego aktem urzędowym.

Po drugie, w doktrynie prezentowane jest stanowisko P. Sarneckiego ${ }^{9}$, w myśl którego akt urzędowy Prezydenta RP analizuje się w dwóch obszarach. W płaszczyźnie formy akt urzędowy wymaga formy pisemnej (dokument na piśmie). Dotyczy to aktów dla potrzeby realizacji obowiązku kontrasygnaty, jak i wykonywania prerogatyw. Akt urzędowy na piśmie, co do zasady, wymaga kontrasygnaty Prezydenta RP. Jednocześnie autor zauważa, że nie wszystkie akty urzędowe wymagają kontrasygnaty, w szczególności te, które nie przybierają formy pisemnej. Zdaniem tego autora występują działania urzędowe, które nie są aktami urzędowymi (np. przemówienia Prezydenta RP, wywiady). Autor wyraźnie wyróżnia akty urzędowe Prezydenta RP i takie działania urzędowe, które tymi aktami urzędowymi Prezydenta RP nie są, ich cechą konstytutywną jest niewładczy charakter. P. Sarnecki wskazuje też na te sfery, które konstytucyjnie wyłączone są ze sfery administracji rządowej i nie wymagają kontrasygnaty, jak obszar funkcjonowania organów wymiaru sprawiedliwości, Narodowego Banku Polskiego, organów zarządzających sprawami radiofonii i telewizji. Autor ten wskazuje, że wymaganie kontrasygnaty „niejako kuchennymi schodami” prowadziłoby sfery te w praktyce pod kuratelę rządu ${ }^{10}$.

7 Zob. A. Rakowska, Kontrasygnata aktów głowy państwa w wybranych państwach europejskich, Toruń 2009, s. 217; W. Sokolewicz, Pomiędzy systemem parlamentarno-gabinetowym a systemem prezydencko-parlamentarnym: prezydentura ograniczona, lecz aktywna w Polsce i w Rumunii, Przegląd Sejmowy 1996, nr 3, s. 54; B. Opaliński, Kontrasygnata aktów głowy państwa w polskim konstytucjonalizmie. Kontrasygnata w Konstytucji Rzeczpospolitej Polskiej z 2 kwietnia 1997, część II, Ius Novum 2011, nr 3, s. 138.

8 Zob. B. Opaliński, Kontrasygnata..., s. 136.

9 Zob. P. Sarnecki, Komentarz do niektórych przepisów Konstytucji Rzeczypospolitej Polskiej, w: Prezydent Rzeczypospolitej Polskiej. Komentarz, 2000 [baza danych LEX].

Tamże, art. 144 Konstytucji RP. 
Co do wymogu kontrasygnaty, P. Sarnecki zaznacza, że literalne podejście do wymogu kontrasygnaty w każdej sytuacji prowadziłoby do paraliżu funkcjonowania państwa. Występować to będzie szczególnie w wypadku konfliktu rządu z głową państwa. Prowadzi to autora do wniosku o szerokiej interpretacji katalogu prerogatyw i dopuszczenia tzw. kompetencji pochodnych, które mieszczą się w danej kompetencji (prerogatywie) Prezydenta RP lub są jej dalszym ciągiem (np. brak konieczności kontrasygnaty przy wycofaniu prezydenckiego projektu ustawy z Sej$\mathrm{mu}$ - art. 119 ust. 4 Konstytucji), jak i dopuszczenia tzw. kompetencji analogicznych.

Po trzecie, w najnowszej literaturze wskazuje się, że akt urzędowy Prezydenta $\mathrm{RP}$ to instytucja, która ma dwa elementy ją konstytuujące: akt ten coś rozstrzyga, zawiera więc element władczy Prezydenta RP oraz wywołuje skutki prawne. Oznacza to, że Prezydent RP może podejmować szereg czynności, które nie są aktami urzędowymi. K. Kozłowski zaznacza, że akt urzędowy jest zastrzeżony dla sytuacji, w których Prezydent RP o czymś rozstrzyga, a zatem realizuje którąś z materii kierownictwa państwowego ${ }^{11}$. Na uwagę zasługuje zaproponowane przez tego autora rozumienie aktu urzędowego jako aktu, który o „czymś rozstrzyga”. Podobne zapatrywanie wyraził B. Szczucki ${ }^{12}$. Autor ten odnosi się też do problematyki obwieszczeń Prezydenta RP i podnosi, że w obwieszczeniu Prezydent RP tylko stwierdza faktyczną liczbę wolnych stanowisk sędziego w Sądzie Najwyższym. Sama liczba stanowisk w tym Sądzie, w jego poszczególnych izbach, ustalona jest w regulaminie Sądu Najwyższego.

B. Szczucki wyraża pogląd, że obwieszczenie Prezydenta RP o wolnych stanowiskach jest czynnością urzędową, podejmowaną na podstawie art. $31 \S 1$ ustawy o Sądzie Najwyższym, nie zaś aktem urzędowym Prezydenta RP. Także w innych poglądach doktryny podkreśla się, że w trakcie sprawowania swojego urzędu Prezydent RP podejmuje również wiele działań, które pomimo uzyskania formy pisemnej nie stanowią aktów urzędowych ${ }^{13}$.

Jest to racjonalne i zgodne z rzeczywistością, skoro Prezydent RP, jako osoba fizyczna, podejmuje szereg czynności i działań, którym nie można przypisać znaczenia prawnego, a tym bardziej charakteru aktu urzędowego, dla których wymagana byłaby każdorazowo kontrasygnata Prezesa Rady Ministrów.

11 Zob. K. Kozłowski, Komentarz do art. 144, w: Konstytucja RP, t. 2. Komentarz. Art. 87-243, red. M. Safjan, L. Bosek, Warszawa 2016, s. 708.

12 Zob. B. Szczucki, Komentarz do art. 31, w: Ustawa o Sądzie Najwyższym. Komentarz, 2018 [baza danych LEX]. Rozróżnienia na akty urzędowe Prezydenta RP i czynności urzędowe dokonuje także I. Lalak, Spór o instytucje kontrasygnaty, w: Ius et Veritas. Księga poświęcona pamięci Michała Staszewicza, red. D. Dudek, A. Janicka, W.S. Staszewski, Lublin 2003, s. 194-195.

13 A. Frankiewicz, Kontrasygnata aktów urzędowych Prezydenta RP, Kraków 2004, s. 104-106. 
W tym kontekście zauważyć należy, że całkowicie niezasadne jest odwoływanie się do argumentów historycznych wynikających z kontrasygnowania przez Prezesa Rady Ministrów zarządzeń i rozporządzeń Prezydenta RP A. Kwaśniewskiego, gdyż zapadły one w odmiennym stanie prawnym i zostały oparte na odmiennie określonej podstawie normatywnej. Argument ten pojawia się w uzasadnieniu postanowienia Sądu Najwyższego z dnia 28 marca 2019 r., III KO 154/18 ${ }^{14}$. Wskazuje on, że wydane w dniu 9 lipca 1998 r. rozporządzenie Prezydenta RP w sprawie ustalenia liczby sędziów i prezesów Sądu Najwyższego opatrzone było kontrasygnatą Prezesa Rady Ministrów ${ }^{15}$, podobnie jak wydane dnia 13 lutego 1996 r. zarządzenie $\mathrm{w}$ tej samej sprawie ${ }^{16}$. Rozporządzenie to wydano na podstawie art. 4 ust. 2 ustawy z dnia 20 września 1984 r. o Sądzie Najwyższym ${ }^{17}$. Przepis ten głosił: „Liczbę sędziów i prezesów Sądu Najwyższego ustala Prezydent Rzeczypospolitej Polskiej na wniosek Krajowej Rady Sądownictwa”. Na tym etapie należy powtórzyć treść art. 31 $\$ 1$ obecnie obowiązującej ustawy o Sądzie Najwyższym, która stanowi aktualną podstawę do wydania obwieszczenia Prezydenta RP o wolnych stanowiskach sędziowskich.

Zgodnie z art. $31 \S 1$ ustawy o Sądzie Najwyższym, Prezydent Rzeczypospolitej Polskiej, po zasięgnięciu opinii Pierwszego Prezesa Sądu Najwyższego, obwieszcza w Dzienniku Urzędowym Rzeczypospolitej Polskiej „Monitor Polski” liczbę wolnych stanowisk sędziego przewidzianych do objęcia w poszczególnych izbach Sądu Najwyższego.

W świetle poprzednio obowiązującego przepisu ustawy o Sądzie Najwyższym z 1984 r. Prezydent RP ustalał (a nie wyłącznie obwieszczał) liczbę sędziów i w tym zakresie należy uznać, że korzystał ze swoich kompetencji i rozstrzygał o liczbie sędziów (stanowisk sędziowskich). Przy tym nie wykonywał tego, konsekwentnie wydając w tym zakresie rozporządzenie ${ }^{18}$. Jednocześnie na tej samej podstawie prawnej (art. 4 ust. 2 ustawy o Sądzie Najwyższym z 1984 r.) dwa lata wcześniej Prezydent RP wydał zarządzenie ${ }^{19}$ pomimo niezmienionego $\mathrm{w}$ treści art. 4 ust. 2 ustawy o Sądzie Najwyższym z 1984 r. (tj. ustalania przez Prezydenta

14 http://www.sn.pl/sites/orzecznictwo/orzeczenia3/iii\%20ko\%20154-18-1.pdf [dostęp: 8.06.2021 r.].

15 Zob. rozporządzenie Prezydenta Rzeczypospolitej Polskiej z dnia 9 lipca 1998 r. w sprawie ustalenia liczby sędziów i prezesów Sądu Najwyższego, Dz. U. z 1998 r. Nr 94, poz. 595.

16 Zob. zarządzenie Prezydenta Rzeczypospolitej Polskiej z dnia 13 lutego 1996 r. w sprawie ustalenia liczby sędziów i prezesów Sądu Najwyższego, M.P. z 1996 r. Nr 12, poz. 135.

17 Dz. U. Nr 45 poz. 241.

18 Zob. rozporządzenie Prezydenta Rzeczypospolitej Polskiej z dnia 9 lipca 1998 r., Dz. U. z 1998 r. $\mathrm{Nr}$ 94, poz. 595.

19 Zob. zarządzenie Prezydenta Rzeczypospolitej Polskiej z dnia 13 lutego 1996 r., M.P. z 1996 r. Nr 12, poz. 135. 
RP liczby sędziów Sądu Najwyższego na wniosek Krajowej Rady Sądownictwa). Oba akty, czyli zarządzenie i rozporządzenie, były kontrasygnowane przez Prezesa Rady Ministrów.

Obecnie w świetle art. $31 \S 1$ ustawy o Sądzie Najwyższym Prezydent RP obwieszcza, a więc spełnia formalny obowiązek informacyjny. Element władczy ustalania liczby sędziów został przeniesiony na podstawie art. 4 ustawy o Sądzie Najwyższym z 2018 r. do $\$ 2$ Regulaminu Sądu Najwyższego ${ }^{20}$. Akt ten ma charakter normatywny, Prezydent RP wykonuje w nim swoje kompetencje władcze i posiada on kontrasygnatę Prezesa Rady Ministrów. Kontrasygnowanie aktu o tożsamej treści i funkcji z 1998 r., a nie dotyczącego obwieszczania o wolnych stanowiskach, odnosi się natomiast do ustalania liczby stanowisk, nie może zatem stanowić żadnego argumentu za koniecznością kontrasygnowania obwieszczenia Prezydenta RP wydanego na podstawie art. $31 \S 1$ obowiązującej ustawy o Sądzie Najwyższym.

Kilka wypowiedzi dotyczy wprost charakteru prawnego obwieszczenia o wolnych stanowiskach sędziowskich w Sądzie Najwyższym i kwestii kontrasygnowania takiej czynności. Na kanwie obwieszczenia Prezydenta RP o wolnych stanowiskach sędziowskich wypowiadał się K. Grajewski ${ }^{21}$. Z jednej strony wyłączył możliwość kreowania kompetencji Prezydenta RP - na zasadzie analogii - jako wolnych od obowiązku kontrasygnaty. Z drugiej strony wskazał, że wymóg rygorystycznego rozumienia obowiązku kontrasygnaty byłby niewskazany. Jego pogląd zdaje się wskazywać, że obwieszczenie o wolnych stanowiskach sędziowskich w Sądzie Najwyższym jest aktem urzędowym Prezydenta RP. Autor ten powołał się jednak na pogląd uzasadniający brak konieczności uzyskania kontrasygnaty, tj. na koncepcję kompetencji pochodnych wynikającą z oczywistej prerogatywy Prezydenta RP ${ }^{22}$. Stwierdzil, że Prezydent RP nie może wykonywać prerogatywy jeżeli KRS nie wskaże kandydatów, a z kolei by ich wyłonić, konieczne jest ogłoszenie, które w obecnym stanie inicjuje właśnie Prezydent RP. Jednocześnie podnosił, że wątpliwość może wywoływać fakt, iż trudno tu mówić „o dalszym ciągu”, skoro ogłoszenie ma miejsce wcześniej niż akt powołania sędziego i prowadzić to może do rozszerzenia kompetencji organu ${ }^{23}$.

20 Zob. rozporządzenie Prezydenta RP z dnia 29 marca 2018 r. - Regulamin Sądu Najwyższego, Dz. U. z 2018 r. poz. 660 z późn. zm.

21 Zob. Prof. Grajewski: Obwieszczenie bez kontrasygnaty to niebezpieczny precedens, 16.07.2018, https:// www.prawo.pl/prawnicy-sady/kontrasygnata-premiera-a-nabor-sedziow-do-sn,234704.html

22 Zob. M. Granat, Opinia na temat konieczności kontrasygnaty aktu Prezydenta o wyznaczeniu Marszałka Seniora, Ekspertyzy i Opinie Prawne. Biuletyn Biura Studiów i Ekspertyz Kancelarii Sejmu 2002, nr 1 (46), s. 95-96.

23 Prof. Grajewski: Obwieszczenie bez kontrasygnaty to niebezpieczny precedens... 
Na kanwie obwieszczenia Prezydenta RP o wolnych stanowiskach sędziowskich M. Florczak-Wątor oraz T. Zalasiński zakwalifikowali obowiązek obwieszczenia jako akt urzędowy Prezydenta RP. Uznali, że jest ono jego nową kompetencją, niemieszczącą się w ramach prerogatywy nominowania sędziów. Autorzy ci odrzucili także koncepcję aktów analogicznych, jak i koncepcję kompetencji pochodnej mieszczącej się w ramach prerogatywy nominowania sędziów przez Prezydenta RP. Jednocześnie jednak uznali, że wymóg kontrasygnaty dla obwieszczenia Prezydenta RP o wolnych stanowiskach sędziowskich w Sądzie Najwyższym jest sprzeczny $\mathrm{z}$ art. $10 \mathrm{i}$ art. 179 Konstytucji $\mathrm{RP}^{24}$.

$\mathrm{Na}$ temat problematyki wymogu uzyskania kontrasygnaty dla obwieszczenia o wolnych stanowiskach sędziowskich na podstawie art. $31 \S 1$ ustawy o Sądzie Najwyższym wypowiedziała się O. Kazalska ${ }^{25}$. Autorka ta uznała, że obwieszczenie o wolnych stanowiskach sędziowskich ma charakter techniczny, tj. czynności urzędowej Prezydenta RP, niebędącej aktem urzędowym. Prezydent RP bowiem „obwieszczając” - realizuje formalny obowiązek informacyjny, a nie "rozstrzyga o czymkolwiek." O. Kazalska powołuje się np. na obwieszczenia Prezydenta RP z dnia 16 listopada 2001 r. o treści oświadczenia złożonego przez osobę ubiegają się o pełnienie funkcji publicznej ${ }^{26}$. Podobnie autorka kwalifikuje obwieszczenie o sprostowaniu błędu czy o ogłoszeniu tekstu jednolitego, które jest autorytatywną urzędową informacją.

Oznacza to w konkluzji - w świetle tego poglądu - brak obowiązku uzyskiwania kontrasygnaty dla czynności obwieszczenia o wolnych stanowiskach sędziowskich. Autorka ta także wskazała na możliwość konstruowania w ramach prerogatyw Prezydenta RP uprawnień pochodnych jako mieszczących się w ramach prerogatywy mianowania sędziów. Wykluczyła raczej stosowanie konstrukcji uprawnień analogicznych. Historycznym argumentem odwołującym się do art. 44 ust. 3 Konstytucji marcowej, było założenie, że akty urzędowe wypływające z prerogatyw Prezydenta Rzeczpospolitej nie wymagały kontrasygnaty ${ }^{27}$. O. Kazalska wskazała, że doktryna prawa konstytucyjnego w odniesieniu do kontrasygnaty odeszła od prostej reguły interpretacyjnej, zgodnie z którą każdy akt urzędowy,

24 Zob. M. Florczak-Wątor, T. Zalasiński, Opinia prawna w sprawie zgodności z Konstytucją obwieszczenia Prezydenta Rzeczypospolitej Polskiej z 24.5.2018 r., Nr 127.1.2018 o wolnych stanowiskach sędziego w Sądzie Najwyższym, wydanego bez kontrasygnaty Prezesa Rady Ministrów, Iustitia 2018, nr 3, s. 135.

25 Zob. O. Kazalska, Zwolnienie z konstytucyjnego wymogu kontrasygnaty-rozważania na tle niekontrasygnowanych obwieszczeń Prezydenta Rzeczpospolitej Polskiej o wolnych stanowiskach sędziego w Sądzie Najwyższym, Studia Iuridica 2018, nr 76, s. 219 i nn.

26 M.P. z 2001 r. poz. 702.

27 Zob. O. Kazalska, Zwolnienie..., s. 222. 
który nie jest wprost wskazany w art. 144 ust. 3 Konstytucji RP, podlega kontrasygnacie. Paraliżowałoby to w praktyce możliwość wykonywania przez Prezydenta RP jego zadań i funkcjii ${ }^{28}$.

Autorka ta, tak jak B. Opaliński, wskazuje na szereg aktów urzędowych Prezydenta RP, które nie wymagają kontrasygnaty, a nie są wprost wymienione w art. 144 ust. 3 Konstytucji (wyjątki od zasady obowiązku kontrasygnaty aktów urzędowych Prezydenta RP). Mowa tu np. o powołaniu postanowieniem przez Prezydenta RP swojego przedstawiciela do Krajowej Rady Sądownictwa na podstawie art. 187 ust. 1 pkt 1 Konstytucji RP ${ }^{29}$. Wskazuje się, że na zasadzie zwyczaju konstytucyjnego nikt nie kwestionuje braku kontrasygnaty $\mathrm{w}$ takim przypadku. Bez kontrasygnaty w takiej sytuacji swoich przedstawicieli w KRS powoływali Prezydenci RP: A. Kwaśniewski, L. Kaczyński, B. Komorowski, co oznaczałoby, że stosując restrykcyjną wykładnię konieczności kontrasygnaty dla wskazywania ich przedstawicieli w KRS, w czasie kadencji tych Prezydentów RP, KRS był niewłaściwie obsadzony ${ }^{30}$. Wymienieni Prezydenci RP mianowali też bez kontrasygnaty sekretarza stanu kierującego Biurem Bezpieczeństwa Narodowego czy swoich przedstawicieli w Komisji Nadzoru Finansowego. Podobnie bez kontrasygnaty Prezydent RP A. Kwaśniewski powoływał swoich przedstawicieli do Rady Fundacji Centrum Badania Opinii Społecznej. Dalej, powołując się na pogląd L. Garlickiego, autorka wskazuje, że kontrasygnaty nie wymaga powołanie przez Prezydenta RP Marszałka Seniora, uzasadniając to stanowisko kompetencją pochodną ${ }^{31}$.

Wynika z tego, że za niewymagających kontrasygnaty - a więc za prerogatywę należy traktować akty urzędowe Prezydenta RP, które nie są literalnie wymienione w art. 144 ust. 3 Konstytucji RP, ale także szereg innych, wśród których wymienia się inicjatywę ustawodawczą Prezydenta RP co do zmiany Konstytucji, prawo wnoszenia poprawek i cofnięcia projektów ustaw w ramach prezydenckiej inicjatywy, zawiadomienie przez Prezydenta RP Marszałka Sejmu o przejściowej niemożliwości sprawowania urzędu. W tym zakresie autorka ma wątpliwości, czy nie są to kompetencje analogiczne, a nie tzw. kompetencje pochodne.

Także B. Opaliński wskazał na możliwość konstruowania w ramach prerogatyw Prezydenta RP uprawnień pochodnych jako mieszczących się $\mathrm{w}$ ramach

28 O. Kazalska, Zwolnienie..., s. 227, a także K. Kozłowski, Komentarz..., s. 709.

29 Zob. O. Kazalska, Zwolnienie..., s. 227; B. Opaliński, Kontrasygnata..., s. 145-146.

30 Zob. B. Szczucki, Prezydent Rzeczpospolitej Polskiej jak organ czuwający nad przestrzeganiem konstytucji, Warszawa 2016, przyp. 97.

31 Zob. L. Garlicki, Komentarz do art. 109, w: Konstytucja Rzeczypospolitej Polskiej. Komentarz, t. 2, red. L. Garlicki, Warszawa 2001. 
prerogatywy ${ }^{32}$. Pogląd swój wsparł orzecznictwem Trybunału Konstytucyjnego, z którego wynika raczej wykluczenie konstrukcji uprawnień analogicznych przy prerogatywach, natomiast można uznać ostrożnie, że TK nie wykluczył całkowicie stosowania koncepcji kompetencji pochodnych ${ }^{33}$.

Przedłużeniem prerogatywy Prezydenta RP określa się w piśmiennictwie kompetencje do powoływania Pierwszego Prezesa Sądu Najwyższego i Prezesów Sądu Najwyższego, Prezesa Naczelnego Sądu Administracyjnego, Prezesa i Wiceprezesa Trybunału Konstytucyjnego ${ }^{34}$.

Dodać należy, że w uprzednim stanie prawnym ogłoszenie o wolnych stanowiskach sędziowskich w Sądzie Najwyższym należało do Pierwszego Prezesa Sądu Najwyższego. Prezes Rady Ministrów w tym modelu postępowania nie mógł zablokować zainicjowania procedury wyboru sędziego. Nie służyła mu bowiem kontrasygnata do takiego aktu. Skoro ustawodawca zmienił model normatywny, a kwestie te niewątpliwe leżą w kompetencjach ustawodawcy zwykłego, wzmacniając prerogatywę Prezydenta RP, to wymóg uzyskania kontrasygnaty dla czynności obwieszczenia, przy konflikcie władz - rządu i Prezydenta RP, prowadziłby do wyłączenia prerogatywy głowy państwa w ogóle, jak i powodowałby wpływ władzy wykonawczej na władzę sądowniczą.

Należy więc dostrzec $\mathrm{w}$ tej mierze ewolucję stanu prawnego.

Sposób interpretacji art. 31 \$ 1 i 2 ustawy o Sądzie Najwyższym z 2018 r. powinien być dokonywany przy założeniu rozsądnego i racjonalnego ustawodawcy i nie może on stwarzać nierozwiązywalnego klinczu w procesie stosowania prawa ${ }^{35}$. Nie można interpretować każdego sposobu wykonywania obowiązku obwieszczenia przez Prezydenta RP zgodnie z art. 31 ustawy o Sądzie Najwyższym jako sprzecznego z Konstytucją, zwłaszcza że ustawa zasadnicza nie jest w zakresie nominowania sędziów aktem samodzielnym i odsyła w uszczegółowieniu procedury do ustawodawstwa zwykłego.

Wymienieni wcześniej autorzy wskazują, że zamknięcie prerogatyw Prezydenta RP w 30 aktach byłoby znacznym uproszczeniem, nieobrazującym rzeczywistego stanu rzeczy, nie do zaakceptowania w praktyce funkcjonowania państwa.

Reasumując, rygorystyczna wykładnia koncepcji prerogatywy jest nie do zastosowania w praktyce i nie jest faktycznie stosowana ${ }^{36}$.

32 Zob. B. Opaliński, Kontrasygnata..., s. 138.

33 Zob. wyrok TK z dnia 23 marca 2006 r., K 4/06, OTK ZU, nr 3A, poz. 32.

34 O. Kazalska, Zwolnienie..., s. 230.

35 Tak w odniesieniu do stosowana prawa S. Wronkowska, Podstawowe pojęcia prawa i prawoznawstwa, Poznań 2003, s. 30 oraz B. Opaliński, Kontrasygnata..., s. 144.

36

Tak też B. Opaliński, Kontrasygnata..., s. 137. 
Nie można uznać, że obwieszczenie o wolnych stanowiskach w Sądzie Najwyższym wymaga kontrasygnaty Prezesa Rady Ministrów, bo nie mieści się w katalogu prerogatyw Prezydenta RP, a jednocześnie, że wymóg kontrasygnaty dla obwieszczenia Prezydenta RP o wolnych stanowiskach sędziowskich w Sądzie Najwyższym byłby sprzeczny z art. $10 \mathrm{i}$ art. 179 Konstytucji RP, gdyż dawałby rządowi - poprzez instytucję kontrasygnaty - wpływ na uruchomienie procedury, której efektem finalnym jest nominowanie sędziów najwyższego organu sądowego w Polsce. Obowiązek uzyskania kontrasygnaty narusza zasadę trójpodziału władzy oraz niezależności sądów i niezawisłości sędziów ${ }^{37}$.

Wreszcie należy zwrócić uwagę na zapatrywanie prawne wyrażone przez W. Sy$\mathrm{cha}^{38}$. Słusznie zauważa on, że przepisy prawa nakładają uprawnienia, kompetencje, ale i obowiązki - także na Prezydenta RP, które nie mieszczą się w formule kompetencji czy uprawnień. Wymóg obwieszczenia można kwalifikować jako ustawowy obowiązek Prezydenta RP, którego wykonanie nie stanowi żadnej kompetencji czy uprawnienia Prezydenta RP (ich wykonywania), gdyż te realizują się w ustaleniu liczby sędziów Sądu Najwyższego w regulaminie tej instytucji, ale należy je traktować jako obowiązek informacyjny wynikający z ustawy. Skutki prawne, jakie można $\mathrm{z}$ tego wywodzić, wynikają dopiero z reakcji na ogłoszenie o wolnych stanowiskach sędziowskich w postaci zgłoszeń na te wolne stanowiska. Na kwestię tę, tj. związania skutków prawnych dopiero ze złożeniem kandydatur przez osoby ubiegające się o stanowisko w Sądzie Najwyższym, a nie samo ogłoszenie o wolnych stanowiskach, zwróciła uwagę O. Kazalska ${ }^{39}$.

Problem kontrasygnowania obwieszczenia Prezydenta RP o wolnych stanowiskach sędziowskich w Sądzie Najwyższym był przedmiotem rozważań Naczelnego Sądu Administracyjnego, w wyrokach z dnia 6 maja 2021 r., II GOK 2/18 ${ }^{40}$, II GOK $3 / 18^{41}$, II GOK 5/18 $8^{42}$, II GOK 6/18 $8^{43}$, II GOK $7 / 18^{44}$. W wyrokach tych NSA uznał, że: „Przyznana Prezydentowi RP kompetencja do ogłoszenia obwieszczenia o wolnych stanowiskach sędziowskich w Sądzie Najwyższym nie stanowi prerogatywy

37 Tak M. Florczak-Wątor, T. Zalasiński, Opinia..., s. 135.

38 Zob. W. Sych, Uzasadnienie do zdania odrębnego SSN Wojciecha Sycha do postanowienia Sądu Najwyższego z dnia 28 marca 2019 r., III KO 154/18, http://www.sn.pl/sprawy/SiteAssets/Lists/Zagadnienia_prawne/AllItems/III_KO_154_18.Uzasadnienie\%20zdania\%20odr\%C4\%99bnego\%20SSN\%20 W.\%20Sycha.pdf.

39 Zob. O. Kazalska, Zwolnienie..., s. 239.

40 https://orzeczenia.nsa.gov.pl/doc/3FF92D5BB1 [dostęp: 21.05 .2021 r.].

41 https://orzeczenia.nsa.gov.pl/doc/D33A0C60B4 [dostęp: 8.06.2021 r.].

42 https://orzeczenia.nsa.gov.pl/doc/A6207FB222 [dostęp: 8.06.2021 r.].

43 https://orzeczenia.nsa.gov.pl/doc/5461FE6C1A [dostęp: 8.06.2021 r.].

44 https://orzeczenia.nsa.gov.pl/doc/1D62BA78B2 [dostęp: 8.06.2021 r.]. 
mającej charakter pochodny względem prerogatywy dotyczącej powołania sędziów”. Stwierdził ponadto, że „podejmowanie decyzji o obwieszczeniu o wolnych stanowiskach sędziowskich w Sądzie Najwyższym przez Prezydenta RP nie stanowi czynności koniecznej do wykonywania prerogatywy polegającej na powoływaniu sędziów Sądu Najwyższego". W konsekwencji uchylił uchwałę KRS o przedstawieniu kandydatur na sędziów Prezydentowi RP, a postępowania umorzył. Należy zauważyć, że twierdzenie drugie o tym, że podejmowanie decyzji o obwieszczeniu o wolnych stanowiskach sędziowskich nie stanowi czynności koniecznej do wykonywania prerogatywy do powoływania sędziów Sądu Najwyższego, jest sprzeczne $\mathrm{z}$ wywiedzionym skutkiem braku kontrasygnaty $\mathrm{w}$ konkursach będących przedmiotem kontroli, w tych konkretnych konkursach i istniejącym stanie prawnym. Uznano bowiem podstawy do umorzenia postępowania. W świetle tego poglądu przy sporze (braku współpracy) premiera i prezydenta ten ostatni nie mógłby wykonywać swojej prerogatywy. Premier zawsze mógłby blokować proces postępowania konkursowego i nominacyjnego ${ }^{45}$. Istniejące rozwiązanie ustawowe zakwestionowano z uwagi na możliwość uznaniowego decydowania o wszczęciu lub braku wszczęcia postepowań konkursowych przez Prezydenta RP. Jest to raczej argument de lege ferenda za zmianą legislacyjną niż rozwiązującą w drodze racjonalnej wykładni istniejący stan prawny wynikający z art. 31 ustawy o Sądzie Najwyższym.

W komentowanych orzeczeniach wskazano tylko jeden argument o braku możliwości zastosowana konstrukcji prerogatywy pochodnej, ale bez głębszego uzasadnienia. Nie jest przekonujące twierdzenie, że obwieszczenie nie stanowi czynności koniecznej do wykonywania omawianej prerogatywy prezydenta. Jednocześnie NSA w ogóle nie rozważył możliwości kwalifikowania obwieszczenia jako obowiązku (czynności urzędowych) nałożonych na prezydenta, które nie mieszczą się w katalogu aktów urzędowych.

\section{Zakończenie}

Reasumując:

1) Obwieszczenie Prezydenta RP wydane w trybie art. $31 \S 1$ ustawy o Sądzie Najwyższym o wolnych stanowiskach sędziowskich w Sądzie Najwyższym jest czynnością urzędową Prezydenta RP. Czynności urzędowe w przeciwieństwie do

45 Zwłaszcza w świetle poglądu, że premier nie jest zobowiązany do kontrasygnowania aktów urzędowych Prezydenta RP, tak w szczególności I. Lalak, Spór o instytucje kontrasygnaty..., s. 196. 
aktów urzędowych Prèzydenta RP nie wymagają kontrasygnaty. Nie można uznać, że techniczna czynność, jaką jest podanie do publicznej wiadomości liczby wolnych stanowisk sędziowskich, jest aktem urzędowym głowy państwa. Stanowi inną czynność urzędową - informacyjną o charakterze technicznym, która nie wymaga kontrasygnaty.

2) W przypadku przyjęcia odmiennego poglądu, tj. zakwalifikowania obwieszczenia Prezydenta RP o wolnych stanowiskach sędziowskich w trybie art. $31 \$ 1$ ustawy o Sądzie Najwyższym, jako aktu urzędowego Prezydenta RP, nie wymaga on kontrasygnaty, gdyż:

a) mieści się to w koncepcji kompetencji pochodnej wynikającej z prerogatywy Prezydenta RP - mianowania sędziów (art. 144 ust. 3 pkt 17 Konstytucji RP); nie ma znaczenia okoliczność, że obwieszczenie poprzedza wykonanie prerogatywy, koncepcja kompetencji pochodnej bowiem nie uzależnia jej zastosowania od koincydencji czasowej wykonywania samej prerogatywy, w szczególności czy akt pochodny ma miejsce przed, czy po wykonywaniu zasadniczej prerogatywy.

b) wymaganie kontrasygnaty byłoby sprzeczne $\mathrm{z}$ Konstytucją - sprzeczne $\mathrm{z}$ art. $10 \mathrm{i}$ art. 179 Konstytucji RP, m.in. z zasadą trójpodziału władzy, i stanowiłoby nieuzasadnioną ingerencję w prerogatywę Prezydenta RP przez Prezesa Rady Ministrów i Rząd. Oznaczałby swoiste „prawo weta” premiera wobec decyzji prezydenta ${ }^{46}$ oraz wpływ władzy wykonawczej na władzę sądowniczą i jej niezależność; c) czynność obwieszczenia o wolnych stanowiskach sędziowskich stanowi obowiązek, a nie uprawnienie Prezydenta RP.

\section{Bibliografia}

Dąbrowski S., Łazarska A., Komentarz do art. 56, w: Prawo o ustroju sądów powszechnych. Komentarz, red. A. Górski, 2013 [baza danych LEX].

Florczak-Wątor M., Zalasiński T., Opinia prawna w sprawie zgodności z Konstytucja obwieszczenia Prezydenta Rzeczypospolitej Polskiej z 24.5.2018 r., Nr 127.1.2018 o wolnych stanowiskach sędziego w Sądzie Najwyższym, wydanego bez kontrasygnaty Prezesa Rady Ministrów, Iustitia 2018, $\mathrm{nr} 3$.

Frankiewicz A., Kontrasygnata aktów urzędowych Prezydenta RP, Kraków 2004.

Garlicki L., Komentarz do art. 109, w: Konstytucja Rzeczypospolitej Polskiej. Komentarz, t. 2, red. L. Garlicki, Warszawa 2001.

46 Tak wyrok TK z dnia 5 czerwca 2012 r., K 18/09; M. Florczak-Wątor, T. Zalasiński, Opinia..., s. 135; O. Kazalska, Zwolnienie..., s. 234; W. Sych, Uzasadnienie... 
Granat M., Opinia na temat konieczności kontrasygnaty aktu Prezydenta o wyznaczeniu Marszałka Seniora, Ekspertyzy i Opinie Prawne. Biuletyn Biura Studiów i Ekspertyz Kancelarii Sejmu 2002, nr 1 (46).

Gudowski J., Ereciński T., Iwulski J., Komentarz do art. 56, Komentarz do Ustawy o Krajowej Radzie Sąownictwa, w: Prawo o ustroju sąów powszechnych. Ustawa o Krajowej Radzie Sąownictwa. Komentarz, red. J. Gudowski, 2009 [baza danych LEX].

Kazalska O., Zwolnienie z konstytucyjnego wymogu kontrasygnaty - rozważania na tle niekontrasygnowanych obwieszczeń Prezydenta Rzeczpospolitej Polskiej o wolnych stanowiskach sędziego w Sądzie Najwyższym, Studia Iuridica 2018, nr 76.

Kozłowski K., Komentarz do art. 144, w: Konstytucja RP, t. 2. Komentarz. Art. 87-243, red. M. Safjan, L. Bosek, Warszawa 2016.

Lalak I., Spór o instytucje kontrasygnaty, w: Ius et Veritas. Księga poświęcona pamięci Michała Staszewicza, red. D. Dudek, A. Janicka, W.S. Staszewski, Lublin 2003.

Opaliński B., Kontrasygnata aktów głowy państwa w polskim konstytucjonalizmie. Kontrasygnata w Konstytucji Rzeczpospolitej Polskiej z 2 kwietnia 1997, część II, Ius Novum 2011, nr 3.

Prof. Grajewski: Obwieszczenie bez kontrasygnaty to niebezpieczny precedens, 16.07.2018, https://www.prawo.pl/prawnicy-sady/kontrasygnata-premiera-a-nabor-sedziow-do-sn, 234704.html.

Rakowska A., Kontrasygnata aktów głowy państwa w wybranych państwach europejskich, Toruń 2009.

Sarnecki P., Komentarz do niektórych przepisów Konstytucji Rzeczypospolitej Polskiej, w: Prezydent Rzeczypospolitej Polskiej. Komentarz, 2000 [baza danych LEX].

Sokolewicz W., Pomiędzy systemem parlamentarno-gabinetowym a systemem prezydencko-parlamentarnym: prezydentura ograniczona, lecz aktywna w Polsce i $w$ Rumunii, Przegląd Sejmowy 1996, nr 3.

Sych W., Uzasadnienie do zdania odrębnego SSN Wojciecha Sycha do postanowienia Sądu Najwyższego z dnia 28 marca 2019 r., III KO 154/18, http://www.sn.pl/sprawy/ SiteAssets/Lists/Zagadnienia_prawne/AllItems/III_KO_154_18.Uzasadnienie\%20 zdania\%20odr\%C4\%99bnego\%20SSN\%20W.\%20Sycha.pdf

Szczucki B., Komentarz do art. 31, w: Ustawa o Sądzie Najwyższym. Komentarz, 2018 [baza danych LEX].

Szczucki B., Prezydent Rzeczypospolitej Polskiej jako organ czuwający nad przestrzeganiem konstytucji, Warszawa 2016.

Wronkowska S., Podstawowe pojęcia prawa i prawoznawstwa, Poznań 2003. 
